2009s-27

\title{
Fair Value Accounting and the Financial Crisis: Messenger or Contributor?
}

Michel Magnan

Série Scientifique
Scientific Series

Montréal

Mai 2009

(C) 2009 Michel Magnan. Tous droits réservés. All rights reserved. Reproduction partielle permise avec citation du document source, incluant la notice (C).

Short sections may be quoted without explicit permission, if full credit, including (C) notice, is given to the source.
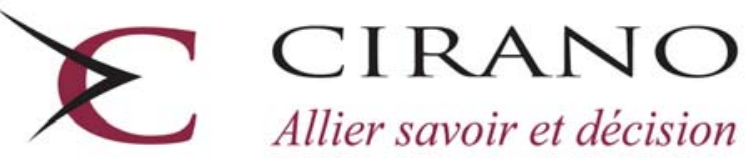

Allier savoir et décision

Centre interuniversitaire de recherche en analyse des organisations 


\section{CIRANO}

Le CIRANO est un organisme sans but lucratif constitué en vertu de la Loi des compagnies du Québec. Le financement de son infrastructure et de ses activités de recherche provient des cotisations de ses organisations-membres, d'une subvention d’infrastructure du Ministère du Développement économique et régional et de la Recherche, de même que des subventions et mandats obtenus par ses équipes de recherche.

CIRANO is a private non-profit organization incorporated under the Québec Companies Act. Its infrastructure and research activities are funded through fees paid by member organizations, an infrastructure grant from the Ministère du Développement économique et régional et de la Recherche, and grants and research mandates obtained by its research teams.

\section{Les partenaires du CIRANO}

\section{Partenaire majeur}

Ministère du Développement économique, de l’Innovation et de l’Exportation

\section{Partenaires corporatifs}

Banque de développement du Canada

Banque du Canada

Banque Laurentienne du Canada

Banque Nationale du Canada

Banque Royale du Canada

Banque Scotia

Bell Canada

BMO Groupe financier

Caisse de dépôt et placement du Québec

DMR

Fédération des caisses Desjardins du Québec

Gaz de France

Gaz Métro

Hydro-Québec

Industrie Canada

Investissements PSP

Ministère des Finances du Québec

Power Corporation du Canada

Raymond Chabot Grant Thornton

Rio Tinto Alcan

State Street Global Advisors

Transat A.T.

Ville de Montréal

\section{Partenaires universitaires}

École Polytechnique de Montréal

HEC Montréal

McGill University

Université Concordia

Université de Montréal

Université de Sherbrooke

Université du Québec

Université du Québec à Montréal

Université Laval

Le CIRANO collabore avec de nombreux centres et chaires de recherche universitaires dont on peut consulter la liste sur son site web.

Les cahiers de la série scientifique (CS) visent à rendre accessibles des résultats de recherche effectuée au CIRANO afin de susciter échanges et commentaires. Ces cahiers sont écrits dans le style des publications scientifiques. Les idées et les opinions émises sont sous l'unique responsabilité des auteurs et ne représentent pas nécessairement les positions du CIRANO ou de ses partenaires.

This paper presents research carried out at CIRANO and aims at encouraging discussion and comment. The observations and viewpoints expressed are the sole responsibility of the authors. They do not necessarily represent positions of CIRANO or its partners. 


\title{
Fair Value Accounting and the Financial Crisis: Messenger or Contributor?
}

\author{
Michel Magnan*
}

\begin{abstract}
Résumé
La comptabilisation à la juste valeur a-t-elle joué un rôle dans la crise financière actuelle ? Cette question fait l'objet de la présente annexe. La comptabilisation à la juste valeur implique que les actifs et les passifs sont mesurés et constatés aux états financiers d'une firme selon leur valeur marchande ou selon de proches substituts. Les recherches universitaires exhaustives qui ont été effectuées au cours des 20 dernières années démontrent que les états financiers reflétant la valeur marchande des actifs ou des passifs fournissent une information pertinente pour les investisseurs. Dans ce contexte, la comptabilisation à la juste valeur n'est que l'indication de mauvaises nouvelles. À l'opposé, il existe un autre axe de recherche qui est très critique à l'égard des avantages attribués à la comptabilisation à la juste valeur et qui s'inquiète du fait que ce modèle fragilise l'essence même de l'établissement des états financiers. Plus particulièrement, certaines études font valoir que la comptabilisation à la juste valeur est difficile à vérifier, qu'elle peut être fondée sur des postulats ou des hypothèses peu fiables et qu'elle accorde trop de pouvoirs discrétionnaires aux gestionnaires en ce qui a trait à l'établissement des états financiers. Ce point de vue laisse donc à penser que la comptabilisation à la juste valeur ne transmet pas nécessairement un message neutre et objectif. Qui plus est, la comptabilisation à la juste valeur crée une dynamique circulaire sur le plan de la présentation de la situation financière puisque les marchés fournissent les données utilisées pour mesurer de nombreux actifs, influençant ainsi les bénéfices constatés qui sont ensuite consultés par les analystes et les investisseurs en vue d'établir la valeur marchande d'une firme. Si les marchés deviennent volatils, comme ce fut le cas au cours des derniers mois, les bénéfices constatés deviennent aussi plus volatils, alimentant ainsi l'appréhension des investisseurs. Par conséquent, la comptabilisation à la juste valeur étant associée à des états financiers plus volatils et moins conservateurs, cela peut avoir permis aux gestionnaires de retarder la constatation et de fausser les perceptions des investisseurs et des organismes de réglementation concernant le rendement et la stabilité financière à la fin de la bulle financière. Toutefois, au retour du balancier, la comptabilisation à la juste valeur peut avoir amplifié leur interprétation de la gravité de la crise financière actuelle, augmentant ainsi certaines tendances négatives.
\end{abstract}

Mots clés : comptabilité à la juste valeur, gouvernance, gestion du risque

\footnotetext{
* Fellow associé, CIRANO, et professeur à l’Université Concordia, à l’école des affaires John Molson et titulaire de la chaire en comptabilité Lawrence Bloomberg; Concordia University, 1455, de Maisonneuve ouest, Montréal, Québec, Canada, H3G 1M8; tél. : 514-848-2424 \# 4145; courriel : mmagnan@jmsb.concordia.ca.
} 


\begin{abstract}
Did fair value accounting play a role in the current financial crisis? This appendix explores the issue. Fair value accounting implies that assets and liabilities get measured and reflected on a firm `s financial statements at their market value, or close substitutes. Extensive academic research done over the past 20 years shows that financial statements that reflect the market values of assets or liabilities provide information that is relevant to investors. In other context, fair value accounting is just a messenger carrying bad news. In contrast, there is also another research stream which is quite critical of the perceived merits of fair value accounting, and which worries about how it undermines what constitutes the core of financial reporting. More specifically, it is argued that fair value accounting is difficult to verify, may be based on unreliable assumptions or hypotheses and provides management with too much discretion into the preparation of financial statements. Hence, according to this view, fair value accounting is not necessarily a neutral or unbiased messenger. Moreover, fair value accounting creates a circular dynamic in financial reporting, with markets providing the input for the measurement of many assets, thus affecting reported earnings which are then used by analysts and investors to assess a firm's market value. If markets become volatile, as has been the case in recent months, reported earnings also become more volatile, thus feeding investors apprehensions. Therefore, since fair value accounting is associated with more volatile and less conservative financial statements and, it may have allowed managers to delay the day of recognition as well as distorted investors and regulators' perceptions of financial performance and stability at the end of the financial bubble. However, once the economic pendulum swung back, fair value accounting may have magnified their views as to the severity of the current financial crisis, hence accelerating some negative trends.
\end{abstract}

Keywords: fair-value Accounting, governance, risk management 


\section{Introduction}

Despite its almost universal adoption by accounting standard setters, the merits of fair value accounting continue to generate intense and passionate debates among academics, businesspeople, regulators or investors. A surprising element underlying these debates is the apparent irreconcilable positions adopted by participants in favour or against fair value accounting. However, the current financial crisis has significantly raised the level and stakes in that discussion, with fair value accounting increasingly being under attack. For instance, the U.S. Congress recently mandated the Securities and Exchange Commission to investigate and report on fair value accounting's contribution to the financial crisis. In reaction, some standard setters such as the Canada's Accounting Standards Board, the Financial Accounting Standard Board and the International Accounting Standard Board have recently introduced temporary provisions waiving some aspects of fair value accounting for financial institutions.

The purpose of the Appendix is to provide additional insights into the role played by fair value accounting in the financial crisis. Since the crisis is still ongoing, there is no direct or formal empirical evidence about such role, which may be perceived, actual or potential. However, by analyzing the conceptual and empirical foundations of fair value accounting, it may be possible to draw some inferences and to assess if and how fair value accounting underlies some of the recent turmoil in financial markets. In that regard, the Appendix aims to achieve the following objectives. First, I intend to provide a brief overview of fair value accounting, including its impact on financial statements. The overview includes a summary of the opposite viewpoints on the merits of fair value accounting. Second, I present and discuss the theoretical and empirical underpinnings of fair value accounting. Thirdly, I analyze the measurement and valuation challenges that arise from the use of fair value accounting. Finally, on the basis of the above analyses, I sketch a tentative framework to understand fair value accounting's role and potential contribution to the financial crisis. While fair value accounting can conceptually apply to all aspects of a firm's financial statements, I will purposefully focus on its application to financial instruments and financial institutions.

\section{Context}

Fair value is defined as the price at which an asset could be exchanged in a current transaction between knowledgeable, willing parties. ${ }^{1}$ For liabilities, fair value is defined as the amount that would be paid to transfer the liability to a new debtor. Under fair value accounting (FVA), assets and liabilities are categorized according to the level of judgment (subjectivity) associated with the inputs to measure their fair value, with three (3) levels being considered. At level 1, financial instruments are measured and reported on a firm's balance sheet and income statement at their

${ }^{1}$ Financial Accounting Standards Board. 2006. Financial Accounting Standard 157 - Fair Value Measurements. Norwalk, CT. 
market value, which typically reflects the quoted prices for identical assets or liabilities in active markets. It is assumed that the quoted price for an identical asset or liability in an active market provides the most reliable fair value measurement because it is directly observable to the market (« mark-to-market»). However, if valuation inputs are observable, either directly or indirectly, but do not qualify as Level 1 inputs, the Level 2 fair value assessment of a financial instrument will reflect a) quoted prices for similar financial instruments in active markets, b) quoted prices for identical or similar financial instruments in markets that are not active, c) inputs other than quoted prices but which are observable (e.g., yield curve) or d) correlated prices. Finally, certain financial instruments which, for example, are customized or have no market, will be valued by a reporting entity on the basis of assumptions that presumably reflect market participants' views and assessments (e.g., private placement investments, unique derivative products, etc.). Such valuation is deemed to be derived from Level 3 inputs and is commonly referred as "mark-tomodel" since it is often the outcome of a mathematical modelling exercise with various assumptions about economic, market or firm-specific conditions. ${ }^{2}$ In all cases, any unrealized gain (or loss) on financial instruments held by an institution translates into an increase (decrease) in its stockholders' equity and, consequently, an improvement (deterioration) in its capitalization ratios. ${ }^{3}$

Detractors, among them David Dodge, the former Governor of the Bank of Canada, argue vehemently that FVA has accelerated and amplified the current financial crisis. ${ }^{4}$ Their argument can be summarized as follows. Starting in 2007, the drop in the price of many types of financial instruments led financial institutions to mark down the asset values reported on their balance sheets, thus weakening their capitalization ratios (let's think about the first write-offs following the start of the subprime crisis). To improve their financial profile and to enhance their safety zone with respect to regulatory capital requirements, these institutions started to sell securities or close down positions on some financial instruments in markets that were increasingly shallow as a result of the emergence of a liquidity crisis. These sales magnified the downdraft in quoted prices, thus bringing additional devaluations, etc. Along these lines, William Isaac, former Chairman of the U.S. Federal Deposit Insurance Corporation, argues that "mark-to-market accounting has been extremely and needlessly destructive of bank capital in the past year and is a major cause of the current credit crisis and economic downturn". 5

However, FVA can count on broad support from the accounting profession, standard setters and regulators. For instance, in a recent speech, Nick Le Pan, Canada's former Superintendent of

\footnotetext{
${ }^{2}$ For more details, see FAS 157 and FAS 159 - The Fair Value Option for Financial Assets and Financial Liabilities.

${ }^{3}$ Currently, while all unrealized gains or losses on financial instruments do affect a firm's stockholders' equity, they do not necessarily directly affect its reported net earnings. Some gains or losses may flow through an intermediate performance measure which is labelled Other comprehensive income and which is distinct from reported net earnings.

${ }^{4}$ See McFarland, J. and J. Partridge. 2008. Mark-to-market' accounting rules fuel debate. The Globe and Mail Report on Business. November 20.

${ }^{5}$ Jeffrey, G. 2008. Mark market debate down as a draw. The Bottom Line, December, p. 27.
} 
Financial Institutions, argued that FVA is only a messenger and should not be criticized for merely reflecting the poor underlying economic outlook. ${ }^{6}$ Barbara Roper, from the Consumer Federation of America, argues that sound accounting principles, such as FVA, led to the exposure of underlying problem assets. In her view, FVA provides more accurate, timely and comparable information to investors than any other accounting alternative.

\section{Theoretical and Empirical Foundations Underlying FVA}

FVA's theoretical and empirical premises are relatively solid. In fact, it is one of the few accounting standard that can be traced back directly to accounting-based scientific research. More specifically, there is consistent empirical evidence, accumulated over the past 20 years, that a firm's stock price is more closely associated with the market value of its underlying financial or real assets than with their historical cost, i.e., their purchase price plus related expenses. ${ }^{7}$ The superior relevance of market-derived values is even more obvious in the case of financial derivatives which historical cost is often close to zero but which market value can fluctuate widely. ${ }^{8}$ In other words, fair values, or marked to market values, have been found to be more relevant indicators of firm value than traditional historical cost-based figures. ${ }^{9}$

An interesting early study on the relevance and implications from FVA was performed by Bernard, Merton and Palepu (1995). For many years, Denmark's accounting standard-setting and banking regulatory authorities have relied on mark-to-market valuation for the assets of their commercial banks. ${ }^{10}$ Bernard, Merton and Palepu find that Danish banks' book values, which reflect mark-to-market valuations, seem to provide more reliable information to investors than historical cost-based figures then provided by U.S. banks. Moreover, they do not find evidence

\footnotetext{
${ }^{6}$ McFarland, J. and J. Partridge. Idem.

7 See, among many papers, Barth, M E, W H Beaver and W R Landsman. 2001. The relevance of the value relevance literature for accounting standard setting: another view. Journal of Accounting and Economics 31, pp 77104; Landsman, W.R. 2006. Fair Value Accounting for Financial Instruments: Some Implications for Bank Regulation. Bank for International Settlements Paper.

${ }^{8}$ Venkatachalam, M. 1996. Value-relevance of banks' derivatives disclosures. Journal of Accounting and Economics 22, pp 327-55.

${ }^{9}$ While studies take many different forms, the most widely used approach closely resembles the following (simplified version of a regression):

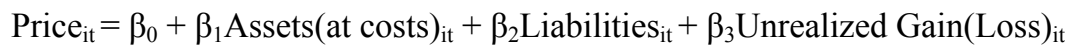

Where i represents a specific firm, and t, a given year-end. Variables are measured in \$, in \$ per share, or standardized by proxies for firm size. Price equals a firm's stock market price while both Assets and Liabilities are as on the balance sheet (consistent with Generally Accepted Accounting Principles). Unrealized Gains(Losses) reflect the difference between an asset market value (according to FVA) and its book value (according to GAAP). FVA-measured information is deemed to be more relevant for investors if results from the regression model show that $\beta_{3}$ is positive and statistically significant.

${ }^{10}$ Bernard, V., R. Merton, and K. Palepu (1995). Mark-to-Market Accounting for Banks and Thrifts:

Lessons from the Danish Experience. Journal of Accounting Research 33 (Spring), 1-32.
} 
that Danish bank executives manipulate mark-to-market numbers to circumvent regulatory capital ratios. However, they also point out that that the Danish and U.S. capital markets are not quite similar and that their findings may not completely hold in a U.S. setting.

On the basis of these empirical findings, many accounting professors have actively lobbied standard setters such as the Financial Accounting Standards Board to 1) introduce FVA into financial statements, initially through footnote disclosure, 2) gradually reduce the relative scope of historical cost-derived assets and liabilities in financial reporting and, 3) modify the conceptual framework underlying standard setting to state more clearly that the primary goal of financial reporting is to provide information that is relevant to investors (presumably, stock market investors) and that, as such, FVA should be emphasized over historical cost ${ }^{11}$ Academic research's influence over the standard setting process has been greatly enhanced by the involvement of many leading accounting professors favouring FVA into the decision-making process of standard setters or regulators such as the FASB or the SEC. ${ }^{12}$ In that regard, it is important to note that there is currently a joint project between FASB and the IASB to adopt a unique conceptual framework for accounting standard-setting. The draft framework, which should be adopted within the next year, clearly states that the main purpose of financial reporting is to provide information that is relevant for investors, with emphasis on market values and cash flow forecasts as the most critical drivers underlying financial reporting. ${ }^{13}$

\section{Measurement and Valuation Challenges}

Despite its many tangible or perceived benefits to investors, the adoption and use of FVA undermines several critical foundations of financial reporting to which we have become accustomed. More specifically, the implementation of FVA explicitly confirms the primacy of financial markets and of investors in the determination of accounting standards. Essentially, the broader social issues and implications arising from accounting standards for stakeholders beyond investors are assumed away.

\footnotetext{
${ }^{11}$ For instance, as early as 2000, the Financial Accounting Standards Committee of the American Accounting Association stated that "..The Committee generally supports the FASB position that financial instruments be reported in the financial statements at fair value..."(Wahlen, J., J.R. Boatsman, R.H. Herz, G. J. Jonas, K.G. Palepu, S.G. Ryan, K. Schipper, C.M. Schrand, D.J. Skinner. 2000. Response to the FASB Preliminary Views: Reporting Financial Instruments and Certain Related Assets and Liabilities at Fair Value. Accounting Horizons 14(4), 501508).

${ }^{12}$ For instance, a leading proponent of FVA, Katherine Schipper, from Duke University (formerly a professor at the University of Chicago) and former President of the American Accounting Association, was a member of the FASB between 2001 and 2006. One of the researchers who pioneered empirical work on FVA, Mary Barth, a professor at Stanford University (formerly at Harvard University) is currently a member of the International Accounting Standards Board and was previously involved in the American Institute of Certified Public Accountants and FASB.

${ }^{13}$ Financial Accounting Standards Board. 2008. Conceptual Framework for Financial Reporting: The Objective of Financial Reporting and Qualitative Characteristics and Constraints of Decision-Useful Financial Reporting Information. Exposure-Draft.
} 
The potential danger of relying on capital markets-based findings to directly prescribe accounting standard has been highlighted more than 30 years ago by Gonedes and Dopuch (1974). ${ }^{14}$ Following a first wave of capital markets-based studies that mapped their findings directly into standard-setting issues, Gonedes and Dopuch explain that observing an empirical relation between accounting amounts and equity prices or returns does not provide sufficient evidence about the desirability or effects of a particular standard, even if markets are informational efficient. Their conclusion rests on the fact that accounting standards are essentially a public good. Therefore, standard setters' mandate and responsibility is to develop standards after making the appropriate social welfare trade-offs, which do involve more parties than just investors. Hence, deciding about a particular accounting standard requires that social preferences be specified. From a different perspective, Holthausen and Watts (2001) put forward the argument that the value-relevance literature has little to say about standard-setting issues. ${ }^{15}$ In their view, without an underlying theory that explains, predicts and links accounting, standard setting, and valuation, value-relevance studies simply report associations.

Other conceptual foundations of traditional financial reporting are also set aside to effectively implement FVA. On one hand, emphasis on value relevance implies that accounting conservatism a remnant of the past. Within a conservatism perspective, financial statements anticipate bad news, i.e., before a transaction is actually done or concluded: hence, an asset is written down if it is deemed that it has suffered a permanent impairment or if expected economic conditions suggest that the firm will not be able to recover its value. Moreover, such write-down is permanent, i.e., the asset will not be re-evaluated upward in the future even if economic conditions change in the meantime. Still within a conservatism perspective, financial statements will only reflect good news if there is an arms' length transaction: the impact of any appreciation in the value of an asset or of the signature of a new contract will be reflected on a firm's financial statements only the asset is actually sold. In contrast, within a FVA perspective, both realized and unrealized losses and gains are recognized on financial statements. Moreover, assets that have been marked down can be re-evaluated upward. As an accounting principle, conservatism traces its roots back to the financial scandals that marked the early twentieth century. Interestingly, some of the firms involved in these scandals were actually using variants

\footnotetext{
${ }^{14}$ Gonedes, N., and Dopuch, N. (1974). 'Capital market equilibrium, information production, and selecting accounting techniques: Theoretical framework and review of empirical work'. Journal of Accounting Research, 12: $48-129$.

${ }^{15}$ Holthausen, R.W., R.L. Watts. 2001. The relevance of the value-relevance literature for financial accounting standard setting. Journal of Accounting \& Economics 31 (1-3), 3-75.
} 
of FVA. ${ }^{16}$ The Enron case also illustrates the potential negative consequences from dropping conservatism and replacing it with mark-to-market accounting, with management strategically selecting bid or ask prices to value its energy contracts. Enron was a key market-maker or, sometimes, the only market-maker, in some markets, thus facilitating managerial discretion. ${ }^{17}$

Reliability as well as verifiability are other financial statements qualities that may be severely undermined by the use of FVA. In light of its emphasis on investor relevance, FVA heavily relies on the estimation of future cash flows or on market-based values. However, as we all know, it is impossible to know the future: one can validate only the rigour and reasonableness of hypotheses and assumptions underlying a forecast. From that standpoint, even market values are essentially forecasts of expected future cash flows. Such a situation provides a striking contrast to historical cost, for which it is possible to verify exactly what is an asset's purchase price, as well as related acquisition costs. Furthermore, in the case of financial instruments that are not traded on an organized market, their valuation for financial reporting purposes relies on numerous assertions by management, assumptions about the appropriate benchmarks or markets, or the reasonableness of a valuation model inputs. Some recent studies show that FVA provides corporate managers with greater discretion in the measurement and recognition of assets and liabilities, thus potentially undermining their reliability. For instance, focusing on accounting for stock options, Aboody, Barth, and Kasznik (2004) find that managers select valuation model parameters to strategically manage estimates of disclosed employee stock option fair values. Their finding raises the broader question of whether managers will behave similarly when selecting model parameters for fair value estimates of other financial instruments. ${ }^{18}$

FVA implicitly assumes that, at the end of each reporting period, an entity sells its assets or settles its liabilities at market or model-estimated prices at that same time. A liquidation balance sheet is not prepared very differently. However, such a view contradicts the going concern assumption which essentially states that a firm is expected to continue its operations for the medium to long term. The going concern assumption is needed for the preparation of regular and consistent financial statements as it underlies the reported values of many other assets and liabilities beyond financial instruments.

By emphasizing market- or model-based measurement, the use of FVA also affects the relative role of accountants in the preparation of financial statements. While historical cost-based financial statements are squarely under the control of accountants, FVA-derived assets and liabilities often require the expertise of other professionals such as actuaries, valuation experts or

\footnotetext{
${ }^{16}$ For example, see Flesher, D. L. and T. Flesher, 1986, Ivar Kreuger's contribution to U.S. financial reporting, The Accounting Review 61 (3): 421-434. Cudahy, R.D.. and W.D. Henderson. 2005. From Insull To Enron: Corporate (Re)Regulation After The Rise And Fall Of Two Energy Icons. Energy Law Journal 26 (1), 35-110.

${ }^{17}$ Weil, R. 2001. After Enron, "mark to market" accounting gets scrutiny. Wall Street Journal (December 4).

${ }^{18}$ Aboody, D., Mary E. Barth, and Ron kasznik. 2004. Firms' voluntary recognition of stock-based compensation expense. Journal of Accounting Research 42(2), 123-150.
} 
financial engineers, with accountants being more likely to play a secondary role, e.g., verifying underlying assumptions, hypotheses, etc.

\section{FVA and the Financial Crisis: Some Thoughts}

It is still too early to conclude on FVA's role in the current financial crisis: not all data is available, additional analyses must be completed and all its consequences cannot be observed. However, relying on prior research findings and on available data, it is possible to draw some inferences about the contribution of FVA to the financial crisis.

\section{More Volatile Financial Results}

Most prior research shows that the adoption of FVA translates into more volatile financial results (earnings). ${ }^{19}$ Hence, financial markets' extreme volatility over the past two years has contributed to raise financial institutions' volatility, potentially amplifying the perception by investors, regulators and governments as to the seriousness of the crisis. More practically, the drop in reported earnings is even more dramatic in light of the record earnings reported in prior years, with FVA pushing down earnings in the current period but boosting earnings in prior years. Two examples illustrate the potential impact of FVA on the volatility of reported earnings.

Crédit Suisse: Within the context of the subprime crisis, the stock market value of most financial institutions depends extensively upon investors' assessment of their direct and indirect exposure to subprime-related loans or derivatives. The valuation information disclosed by financial institutions that evolve in the same markets largely influences such an assessment, with more recent market quotes driving such valuation. In that regard, the saga surrounding Crédit Suisse's release of its 2007 earnings is quite enlightening. On February 12, 2008, Crédit Suisse reports record income from continuous operations of 8.5 billion Swiss Francs. On February 19, 2008, Crédit Suisse announces that some additional control processes have led to the repricing of certain asset-backed positions in its Structured Credit Trading business, with the current total fair value reduction of these positions being reduced by an estimated \$U.S. 2.85 billion. Finally, on March 20, 2008, Crédit Suisse reports that its 2007 operating income has been revised downward by 1.18 billion Swiss Francs (789 million Swiss Francs after tax), close to a 10\% difference with the initially reported figure. The Crédit Suisse story illustrates the difficulty of pinning down the fair value of many assets when the underlying valuation methodology is complex and subject to shifting hypotheses and assumptions about the future. Crédit Suisse`s experience also shows that

\footnotetext{
${ }^{19}$ For example, Barth, Landsman and Wahlen (1995) show that fair value-based measures of net income are more volatile than historical cost-based measures (Barth, Mary E, Landsman, Wayne R, Wahlen, James M.1995. Fair value accounting: Effects on banks' earnings volatility, regulatory capital, and value of contractual cash flows. Journal of Banking \& Finance 19 (3-4), 577-605.)
} 
reported results for a given period may be subject to a wide margin of error, or discretion, or even restated.

Lehman Brothers: In its last reported financial statements before it went bankrupt, Lehman Brothers reported a loss of \$U.S. 2.4 billion for the first six months ended May 31, 2008 (vs. a net income of \$U.S. 2.4 billion for the first six months ended May 31, 2007). The shift of \$U.S. 4.8 billion in net income is largely driven by a dramatic fall of \$U.S. 8.5 billion in Lehman's revenues from principal transactions, which include realized and unrealized gains or losses from financial instruments and other inventory positions owned. A significant portion of the downward shift in principal transactions revenues is actually explained by unrealized losses of \$U.S. 1.6 billion in the first semester of 2008 vs. unrealized gains of \$U.S. 200 million in the first semester of 2007. Thus, accounting at fair value for some financial assets amplified Lehman's downward earnings performance.

Hence, it can be put forward that FVA, through its magnifying impact on earnings volatility, may have contributed to aggravate investors', regulators' and governments' perceptions with respect to the severity of the crisis, itself characterized by record volatility in the prices of many securities and goods.

On a related note, the increased volatility brought forward by FVA is conducive to the use of equity-based compensation, especially stock options, which value is then enhanced (according to the Black-Scholes model, volatility is one of the key inputs in option valuation). Prior research suggests that there is a strong association between performance volatility and the use of stock options. ${ }^{20}$ Through FVA, the outcomes from aggressive risk-taking in investment and financing strategies will directly flow into reported earnings, thus further leveraging the potential gains to be derived from stock options and other incentives. Many financial institutions involved in the current crisis made extensive use of stock options and other incentives, allowing unrealized gains on assets to be converted into cold hard cash.

Does FVA Reflect Underlying Business Performance or Allow Financial Institutions to Delay the Day of Recognition?

\footnotetext{
${ }^{20}$ See, for example, Magnan, Michel. 2006. Les options sur actions : création de richesse pour les actionnaires ou enrichissement des dirigeants au détriment des actionnaires ? Finance-contrôle-strategie 9(3): 221-235.
} 
Some of the fiercest critics of FVA argue that, far from enhancing transparency and relevant financial reporting, it actually provides corporate managements with ways to avoid the day of recognition and to delay asset impairments. In other words, the adoption FVA undermines financial statements' conservatism and leads to changes in managerial behaviour. For instance, Ross Watts (Massachusetts Institute of Technology) argues that the elimination of conservatism brought by FVA leads to the capitalization of unverifiable future cash flows unto the balance sheet. ${ }^{21}{ }^{22}$ Such unverifiability and managerial opportunities to make strategic valuation choices introduce significant noise into the financial reporting process that may be costly to investors. Moreover, by moving firms away from transaction-based accounting, FVA is contradicting SEC efforts to tighten revenue measurement and recognition standards to ensure that only completed sales transactions get reported into the financial statements and affect earnings. ${ }^{23}$ Experience shows that, until the advent of SAB 101, several firms had applied aggressive revenue recognition criteria that dramatically boosted reported earnings and growth rates. Earnings restatements following the enactment of SAB 101 were often sizable and led to significant stock price falls, even if reported cash flows were not affected. In other words, conservative accounting provides information that is useful beyond the estimated cash flows from a particular contract and protects investors and creditors from managerial opportunism.

The case of Lehman Brothers illustrates Ross' argument. As of November 30, 2007, 75.1\% of assets measured at fair value were measured according to Level 2 or Level 3 inputs. In other words, the large majority of assets supposedly valued at fair value were not valued on the basis of directly observable quoted prices. By May 31, 2008, that proportion had increased to $81.7 \%$ of assets measured at fair value, suggesting that barely $18 \%$ of assets supposedly valued according to FVA were "marked to market". Further empirical work as well as the liquidation of Lehman Brothers will provide additional evidence regarding the extent to which its assets may have been overstated or purposely shifted into Levels 2 or 3 to hide developing losses and give management more discretion. At the very least, its actions suggest that FVA reporting may work well for investors when assets trade in deep and efficient markets but may become less transparent when market conditions become more difficult or less liquid. On that note, it is telling that Lehman Brothers was an early adopter of both SFAS 157 (Fair Value Measurements) and SFAS 159 (Option for fair value measurement), deciding to implement their provisions in the first quarter of its 2007 fiscal year.

\footnotetext{
${ }^{21}$ Watts, Ross. 2003. Conservatism in accounting part I: Explanations and Implications. Accounting Horizons 17(3), 207-221.

${ }^{22}$ There is empirical evidence that effective auditing of FVA derived numbers requires very specialized valuation knowledge which may be difficult for auditors to gain and maintain (Martin, R.D., J.S. Rich, T.J. Wilks. 2006. Auditing Fair Value Measurements: A Synthesis of Relevant Research. Accounting Horizons 20(3), 287-303.

${ }^{23}$ For instance, in 1999, the Securities and Exchange Commission issued Staff Accounting Bulletin 101 - Revenue Recognition in Financial Statements which prescribes specific criteria to indicate when a transaction has been concluded, thus considerably reducing managerial discretion in the recognition of revenues. In contrast, fair value accounting does not rely on the conclusion of a transaction to estimate the value of an financial asset or contract.
} 
The Lehman case, as well as many others, raises the issue of FVA applicability as it is being extended from instruments traded in liquid and organized markets to credit-type instruments that are often securitized and which are not quite transparent about their underlying assets. The valuation of these credit-type instruments is made difficult by the lack of direct information, with heavy reliance on credit rating agencies' opinions. Moreover, the market for these instruments is not as deep and liquid than traditional instruments such as bonds, equities or foreign currencies. It does appear that markets were not as efficient as they should have been in assessing the value of these structured investment vehicles or securitized pools of assets and may have relied too much on the judgment of parties such as credit rating agencies which themselves had partial information and were facing some potential conflicts of interests (since they charged fees to render opinions on specific securities).

\section{Accounting and the Market: Mirrors Facing Each Other}

The integration of market values on corporate balance sheets mandated by accounting standard setters contrasts with the trend by many analysts and sophisticated investors to use financial statement data to gauge whether a firm's stock market value has moved away from its fundamental or "intrinsic value." 24 These divergent trends raise a fundamental question as to the grounding of financial statements. More specifically, MacIntosh, Shearer, Thornton and Welker argue that the market uses accounting earnings, along with other information, to value firms' stock and other securities. ${ }^{25}$ However, the prices of many of these securities underlie derivatives' prices, which then find their way into financial statements through FVA, thus completing a circular sequence! As MacIntosh et al. say: "Companies' earnings determine security prices, which determine derivative prices, which determine companies' earnings In short, neither the accounting sign nor the financial market sign appear to be grounded in any external reality. Instead, each model appeals to the other model for the only "reality check" available."

Lehman Brothers' equity-based compensation illustrates the self-referential sequence that FVA introduces into financial reporting and stock market prices. In 2007, Lehman granted close to $39,000,000$ deferred share units to its executives and employees. On the basis of the firm's quoted stock price on the dates at which these grants were made, the overall value of the grant was around $\$ 2.7$ billion. Since 2006, SFAS 123 has mandated the measurement and recognition

\footnotetext{
${ }^{24}$ See, for example, Lee, M.C., J. Myers, and B. Swaminathan. 1999. What is the intrinsic value of the Dow? The Journal of Finance 54(5), 1693-1741.

${ }^{25}$ MacIntosh, N.B., T. Shearer, D.B. Thornton, M. Welker. 2000. Accounting as simulacrum and hyperreality: Perspectives on Income and Capital. Accounting, Organizations and Society 25(1), 13-
} 
of equity-based compensation at fair value, using an amortization method for grants that have a long-term vesting period, bringing Lehman Brothers' expense for equity-based compensation in 2007 to $\$ 1.8$ billion, close to $25 \%$ of earnings before income taxes and equity-based compensation expenses. Hence, on the one hand, the amount reflected as an expense by Lehman on its financial statements reflects the current quoted price of its stock at grant date. On the other hand, investors rely on Lehman's reported earnings to assess its prospects and value its stocks. The chain of decisions exactly matches the above quote from MacIntosh et al. In addition to equity-based compensation, a significant proportion of Lehman Brothers' assets were stocks and stock-based derivatives (more than a third of its FVA assets). Since shares traded on a stock market are all affected to a varying degree by the same secular trends and fluctuations, one can argue that Lehman Brothers earnings and its stock price were mutual reflections of one another, possibly detached from underlying real operations. Such a conclusion can probably be extended to many financial institutions deeply involved in the current crisis or engulfed by it.

\section{Interface between Financial Reporting and Regulatory Capital}

One key criticism against FVA is that its use in the current crisis has led to a reduction in the value of financial institutions' assets, which translated into a severe shrinking of their capital ratios, forcing them to deleverage and sell further assets at distressed prices, thus feeding the downward spiral. However, in that scenario, the issue is not necessarily the accounting itself but how financial regulators use accounting information. In other words, FVA-based financial reporting is only the messenger that a firm's solvency is undermined by its financial strategies or lending practices, but it is up to regulators to figure out how to use such information. ${ }^{26}$

\section{Messenger or Contributor?}

The above discussion suggests that assigning a messenger role to accounting potentially downplays its actual importance and relevance to the current crisis since the message is not neutral but conditioned by accounting standards. However, two issues arise from the use of FVA-derived information in regulatory oversight. First, FVA information is highly volatile and unstable. For example, according to FVA, the wild fluctuations of the stock market over the past few weeks, with many daily closings showing gains or losses from the preceding day of between $5-10 \%$, imply similar fluctuations in any stock market-based assets. Hence, a firm may be solvent one day (assuming a large stock market gain), insolvent the next two days (assuming large stock market losses), and solvent again on the fourth day! While informative, is FVA-based

\footnotetext{
${ }^{26}$ For instance, Irene Wiecek from the University of Toronto argues that “...the credit crisis is not the fault of accounting. It is the fault of overly lenient lending practices". On top of that, she says there was a lack of oversight and regulation in this area" (G. Jeffrey, 2008).
} 
financial reporting useful to regulators in planning and timing their interventions? The answer is that FVA information alone is probably necessary but is not sufficient. Other performance and risk metrics are needed to identify the targets of regulatory actions. A similar argument can be used to justify that FVA information is not sufficient for long term governance purposes as it is not stable enough and difficult to verify. In some sense, the reliance on FVA-based information may have two opposite implications regarding the length and severity of the current crisis. On one hand, the discretion underlying FVA figures have allowed managers to delay the day of recognition when underlying subprime assets started to unravel. Moreover, the additional volatility that it introduces into financial statements may have amplified the impression of financial performance and stability in the bubble period. On the other hand, once the values of underlying assets started crashing, FVA induced balance sheet realignments and recapitalizations may have further magnified the crisis. ${ }^{27}$

Second, some argue that FVA values are actually a red herring and that the real issue is the quality of the accompanying disclosure. ${ }^{28}$ For example, Susan Schmidt, a former governor of the Federal Reserve Board and bank CFO argues that the focus should be on disclosure so that everyone, regulators and investors alike, understand the drivers behind fair value estimates. Actually, FVA derived can be deceptive: up until close to the crisis, both Lehman Brothers and AIG appeared solvent and sufficiently capitalized, with significant portions of their balance sheet relying on FVA. However, what the FVA point estimate values did not tell was the extent of the downfall risk both firms were facing if events did not evolve according to expectations, Lehman because of its exposure to collateralized debt obligations and AIG because of its exposure to credit-default swaps. Looking at both firms' financial statements before the crisis, it would have been difficult to assess the potential magnitude of losses to be incurred because of these exposures. Hence, it can be ventured that FVA without adequate additional disclosure is neither fair nor a good reflection of value that is at risk.

\section{Conclusion}

\footnotetext{
${ }^{27}$ In that regard, it may be useful to note that other accounting standards beyond FVA may have played a role in the willingness of financial institutions to embark on a subprime asset growth strategy. One such standard relates to the recognition of gains upon the securitization of pools of assets ("sale accounting"). Essentially, under certain conditions, accounting practices allow for the accelerated recognition of gains upon the securitization of long-term assets, even if cash flows are spread out over many years. For instance, it has been reported that it was popular for banks that issued Collaterized Debt Obligations and similar instruments to retain the super-senior tranche and, at the same time, buy Credit Default Swaps from third parties. Since the cash portion held by the bank paid a higher spread that the cost to insure the bond, the bank was allowed to report upfront the amount of the difference to be realized over the life of the contract (Otherwise called a negative-basis trade). Earlier in 2008, AIG, the failed insurance giant, was forced by its auditor, PriceWaterhouseCoopers, to stop this practice as it was deemed that under current market conditions, it was impossible to reliably quantify the spread differential. For AIG, the shift in accounting practice translated into billions of dollars in write-offs (Credit Investment News, February 18, 2008, pp. 1 and 10.).

${ }^{28}$ Leone, M. 2008. Fair Value: It's the Disclosure, Stupid. CFO.com. November, 20.
} 
The purpose of the appendix was to briefly present fair value accounting, its origins, application and implications for financial reporting as well as its potential role during the current financial crisis. While no definite conclusion can be reached at this early stage, there is reason to believe that fair value accounting is more than just a messenger carrying bad news and, therefore, may have contributed to the acceleration of the crisis, especially in the financial sector. While the relevance of fair value accounting for investors cannot be questioned, its other qualities (or weaknesses) may have been overlooked by standard setters and regulators.

Fair value accounting for financial instruments is part of a broader trend in accounting standard setting to move away from "accounting" toward estimating expected future cash flows and incorporating into financial statements, i.e., "forecounting". 29 The trend undermines decades if not centuries of accounting practices and concepts such as conservatism and verifiability and requires a completely set of valuation skills and knowledge from accountants. The current crisis constitutes the first serious challenge to this trend, and to fair value accounting in particular, and is likely to generate abundant empirical research over the next few years which will allow us to better assess the pros and cons of fair value accounting.

However, if not fair value accounting, what else? Standard-setters, and many accounting academics, argue that there is no alternative measurement or reporting model. ${ }^{30}$ For instance, Barth (2007, p. 12), a member of the International Accounting Standards Board, argues that "Although opponents of more comprehensive use of fair value have some legitimate concerns, standard setters are unaware of a plausible alternative." In contrast, Watts (2003, p. 219) argues that accounting standard setters should focus on accountants' core competence, i.e., “...providing verifiable conservative information that market participants can use both as inputs in their own valuation and as calibration for their own and others' unverifiable information"31 As such, I would argue that the debate is at two levels: Barth is talking about the measurement of a final output while Watts refers to the validity of the various measurement inputs, the output being of some importance but mostly in terms of providing financial statement users and other stakeholders to adapt, modify or "test-drive" the resulting output. Beyond fair values, measurement assumptions and hypotheses are probably more critical since they allow users to reconstruct the reality according to their own priors.

\footnotetext{
${ }^{29}$ Magnan, Michel; Cormier, Denis. 2005. From Accounting to "Forecounting". Canadian Accounting Perspectives 4(2): 243-257.

${ }^{30}$ Barth, Mary. 2007. Standard-Setting Measurement Issues and the Relevance of Research. Accounting and Business Research, Special Issue, 7-15.

${ }^{31}$ Watts, R.L. 2003. Open citation.
} 
However, underlying the debate, one must not lose sight that various financial and economic interests are at play - additional powers for standard setters, additional business for providers of accounting and valuation services, increased uncertainty about their bonuses for managers and executives, etc. Hence, viewpoints and arguments from interested parties must be reframed accordingly.

The debate goes further than accounting and financial reporting and deals with the essence of what accountants are expected to contribute to society and, implicitly, what competences and skills they must possess to deliver in that regard. One may surmise that current accounting standards, such as those relating to fair value, probably overstretch accountants' capabilities and prior learning and obscure other informational needs by investors and other interested stakeholders. 


\section{References}

Aboody, D., Mary E. Barth, and Ron Kasznik. 2004. Firms' voluntary recognition of stock-based compensation expense. Journal of Accounting Research 42(2), 123-150.

Barth, Mary. 2007. Standard-Setting Measurement Issues and the Relevance of Research. Accounting and Business Research, Special Issue, 7-15.

Barth, M E, W H Beaver and W R Landsman. 2001. The relevance of the value relevance literature for accounting standard setting: another view. Journal of Accounting and Economics 31, pp 77-104.

Barth, Mary E, Landsman, Wayne R, Wahlen, James M.1995. Fair value accounting: Effects on banks' earnings volatility, regulatory capital, and value of contractual cash flows. Journal of Banking \& Finance 19 (3-4), 577-605.

Bernard, V., R. Merton, and K. Palepu (1995). Mark-to-Market Accounting for Banks and Thrifts: Lessons from the Danish Experience. Journal of Accounting Research 33 (Spring), 1-32.

Cudahy, R.D.. and W.D. Henderson. 2005. From Insull To Enron: Corporate (Re)Regulation After The Rise And Fall Of Two Energy Icons. Energy Law Journal 26 (1), 35-110.

Financial Accounting Standards Board. 2008. Conceptual Framework for Financial Reporting: The Objective of Financial Reporting and Qualitative Characteristics and Constraints of Decision-Useful Financial Reporting Information. Exposure-Draft. Norwalk, CT.

Financial Accounting Standards Board. 2006. Financial Accounting Standard 157 - Fair Value Measurements. Norwalk, CT.

Financial Accounting Standards Board. 2006. Financial Accounting Standard 159 - The Fair Value Option for Financial Assets and Financial Liabilities. Norwalk, CT.

Flesher, D. L. and T. Flesher, 1986, Ivar Kreuger's contribution to U.S. financial reporting, The Accounting Review 61 (3): 421-434.

Gonedes, N., and Dopuch, N. 1974. Capital market equilibrium, information production, and selecting accounting techniques: Theoretical framework and review of empirical work. Journal of Accounting Research, 12: 48-129.

Holthausen, R.W. and R.L. Watts. 2001. The relevance of the value-relevance literature for financial accounting standard setting. Journal of Accounting \& Economics 31 (1-3), 3-75.

Jeffrey, G. 2008. Mark market debate down as a draw. The Bottom Line, December, p. 27.

Lee, M.C., J. Myers, and B. Swaminathan. 1999. What is the intrinsic value of the Dow? The Journal of Finance 54(5), 1693-1741. 
Landsman, W.R. 2006. Fair Value Accounting for Financial Instruments: Some Implications for Bank Regulation. Bank for International Settlements Paper

Leone, M. 2008. Fair Value: It's the Disclosure, Stupid. CFO.com. November, 20.

McFarland, J. and J. Partridge. 2008. Mark-to-market' accounting rules fuel debate. The Globe and Mail - Report on Business. November 20.

MacIntosh, N.B., T. Shearer, D.B. Thornton, M. Welker. 2000. Accounting as simulacrum and hyperreality: Perspectives on Income and Capital. Accounting, Organizations and Society 25(1), 13-60.

Magnan, Michel. 2006. Les options sur actions : création de richesse pour les actionnaires ou enrichissement des dirigeants au détriment des actionnaires ? Finance-contrôle-strategie 9(3): 221-235.

Magnan, Michel; Cormier, Denis. 2005. From Accounting to "Forecounting". Canadian Accounting Perspectives 4(2): 243-257.

Martin, R.D., J.S. Rich, T.J. Wilks. 2006. Auditing Fair Value Measurements: A Synthesis of Relevant Research. Accounting Horizons 20(3), 287-303

Venkatachalam, M. 1996. Value-relevance of banks' derivatives disclosures. Journal of Accounting and Economics 22, pp 327-55.

Wahlen, J., J.R. Boatsman, R.H. Herz, G. J. Jonas, K.G. Palepu, S.G. Ryan, K. Schipper, C.M. Schrand, D.J. Skinner. 2000. Response to the FASB Preliminary Views: Reporting Financial Instruments and Certain Related Assets and Liabilities at Fair Value. Accounting Horizons 14(4), 501-508

Watts, Ross. 2003. Conservatism in accounting part I: Explanations and Implications. Accounting Horizons 17(3), 207-221.

Weil, R. 2001. After Enron, "mark to market" accounting gets scrutiny. Wall Street Journal (December 4). 